Review

\title{
Formation and Maintenance of Tissue Resident Memory CD8+ T Cells after Viral Infection
}

\author{
David J. Topham*(D, Emma C. Reilly, Kris Lambert Emo and Mike Sportiello(D) \\ David H. Smith Center for Vaccine Biology and Immunology, Department of Microbiology and Immunology, \\ University of Rochester Medical Center, Rochester, NY 14642, USA; emma_reilly@urmc.rochester.edu (E.C.R.); \\ kris_lambert@urmc.rochester.edu (K.L.E.); michael_sportiello@urmc.rochester.edu (M.S.) \\ * Correspondence: david_tophamr@urmc.rochester.edu; Tel.: +1-585-273-1400
}

Received: 25 September 2019; Accepted: 16 October 2019; Published: 18 October 2019

check for updates

\begin{abstract}
Tissue resident memory $\left(\mathrm{T}_{\mathrm{RM}}\right) \mathrm{CD} 8 \mathrm{~T}$ cells comprise a memory population that forms in peripheral, non-lymphoid tissues after an infection that does not recirculate into the bloodstream or other tissues. $\mathrm{T}_{\mathrm{RM}}$ cells often recognize conserved peptide epitopes shared among different strains of a pathogen and so offer a protective role upon secondary encounter with the same or related pathogens. Several recent studies have begun to shed light on the intrinsic and extrinsic factors regulating $\mathrm{T}_{\mathrm{RM}}$. In addition, work is being done to understand how canonical "markers" of $\mathrm{T}_{\mathrm{RM}}$ actually affect the function of these cells. Many of these markers regulate the generation or persistence of these $T_{R M}$ cells, an important point of study due to the differences in persistence of $T_{R M}$ between tissues, which may impact future vaccine development to cater towards these important differences. In this review, we will discuss recent advances in $T_{R M}$ biology that may lead to strategies designed to promote this important protective immune subset.
\end{abstract}

Keywords: T cell; memory; tissue resident; immune response

\section{Introduction}

As early as 1994, Walter Gerhard's lab demonstrated that protection from a serologically distinct strain of influenza in immune mice was largely due to cross-reactive CD4 and CD8 T cells, with CD8 T cells having the greatest effect in the airways and lung [1]. This form of immunity, called heterosubtypic protection, was effective but short-lived and waned over several months. In 2001, David Woodland's lab used a different respiratory pathogen, Sendai (parainfluenza) virus, to demonstrate that functional virus-specific CD8 T cells persisted in the airways and lungs. However, they observed a similar decline in numbers over a year after infection [2], and the number of virus-specific CD8 T cells in the airways correlated with protection. These studies pre-date the identification of cell surface markers used to define $\mathrm{T}_{\mathrm{RM}}$ cells, although Hogan et al. did measure CD69 expression [2]. In the same year, David Masopust and Leo Lefrancois used major histocompatibility complex (MHC) tetramers carrying viral or bacterial-specific peptides to show that after a systemic infection, pathogen-specific memory CD8 T cells localized to all peripheral non-lymphoid after infection [3]. In 2004, inspired by this data, our lab used an influenza virus model to demonstrate that Very Late Antigen-1 (VLA-1) (the CD49a/CD29 $\alpha 1 \beta 1$ integrin heterodimer) was essential to maintain virus-specific CD8 memory $T$ cells in the airways and lung tissues [4]. In that same study, we found virus-specific CD8 $T$ cells expressing VLA-1 in every peripheral tissue examined, showing that infection of a tissue is not a prerequisite for $\mathrm{T}_{\mathrm{RM}}$ localization. Overall, these results indicate that infection results in populations of CD49a+, CD69+, CD8+ memory T cells that reside in peripheral tissues: tissue resident memory $\mathrm{T}$ cells. [4]. Given the importance of this memory $\mathrm{T}$ cell population to secondary immune protection, 
here we review recent advances in the understanding of $\mathrm{T}_{\mathrm{RM}}$ and call for further research that will lead to strategies designed to improve local tissue immunity.

\section{Markers Used to Define $T_{R M}$}

Expression of several cell surface proteins have been found to be common among $\mathrm{T}_{\mathrm{RM}}$ from different tissues. Absence of chemokine receptor 7 (CCR7) and expression of CD69 were identified early [5,6], and CD49a or VLA-1 came next [4]. At the time, reagents to study mouse CD49a were limited in availability, so this marker was not initially widely adopted. In 2005, CD103 expression was found to define a population of memory T cells in the tonsil [7] and in 2010, the Bevan lab associated CD103 with $\mathrm{T}_{\mathrm{RM}}$ in the brain [8]. Since then, CD69 and CD103 expression have been the most widely used markers of $\mathrm{T}_{\mathrm{RM}}$, although more recent studies in both mice and humans have demonstrated the importance of CD49a. It may be necessary to use these three markers (CD69, CD49a, CD103) in combination when studying $\mathrm{T}_{\mathrm{RM}}$ from different tissues, as it is unlikely to be a homogenous population as previously assumed. Many studies of function and gene expression of $\mathrm{T}_{\mathrm{RM}}$ have relied on either CD69 or CD103 alone or in combination $[9,10]$. Although CD69 is critical for $\mathrm{T}_{\mathrm{RM}}$ in some peripheral tissues (e.g., kidney), it does not appear to be a universal requirement for $\mathrm{T}_{\mathrm{RM}}$ in all sites [11]. Our lab has recently discovered that using CD49a and CD103 in combination identifies up to four potentially distinct memory $\mathrm{T}$ cell subsets in the lungs and airways (including trachea), although cells expressing only CD69 and CD103 do not appear to persist long-term [12]. Using all three markers may be necessary to paint the full picture of cell diversity, function, and gene expression profiles (Table 1).

Table 1. Cell Surface Expression of Markers on Memory CD8 T cell subsets in the airways and lung tissue.

\begin{tabular}{lcccccccccc}
\hline Memory type & Abbreviation & CD3 & TCRb & CD8 & CD44 & CD62L & CD69 & CD49a & CD103 \\
\hline Effector & $\mathrm{EM}$ & + & + & + & high & low & - & - & - \\
\hline Epithelial $\mathrm{T}_{\mathrm{RM}}$ & $\mathrm{eT}_{\mathrm{RM}}$ & + & + & + & high & low & + & + & + \\
\hline Interstitial $\mathrm{T}$ & $\mathrm{RM}$ & $\mathrm{iT}_{\mathrm{RM}}$ & + & + & + & high & low & + & + & - \\
\hline Epithelial Effector & $\mathrm{eeT}$ & + & + & + & high & low & + & - & + \\
\hline $\begin{array}{l}\text { Note: "+" indicates positive cell surface expression; "-" indicates the cell population is negative for cell surface } \\
\text { expression "high" and "low" refer to the levels of cell surface expression. }\end{array}$ & & &
\end{tabular}

\section{Functions of Memory T Cell Markers}

The cell surface proteins used to define $\mathrm{T}_{\mathrm{RM}}$ and other memory subsets are not just markers; they have functions, though relatively little has been done to discern these functions [13]. Naïve T cells lack expression of CD49a and CD69 and have only low levels of CD103 on their surface. Instead, they can be defined by high expression of CD62L (L-selectin), low expression of CD44, and expression of CCR7 [14]. CD62L is a ligand for a receptor expressed on high endothelial venules to help direct naïve T cells to secondary lymphoid organs (SLOs) [15]. CCR7 serves a similar purpose by receiving CCL19 and CCL21 chemokine signals coming from SLOs $[16,17]$. CD44 binds hyaluronic acids in the extracellular matrix of almost all tissues and may itself be important for regulation of $\mathrm{T}$ cell motility, positioning, and retention in peripheral and lymphoid tissues [18,19].

"Central memory T cells" ( $\left.\mathrm{T}_{\mathrm{CM}}\right)$ are CD44 ${ }^{\text {high }}, \mathrm{CD} 62 \mathrm{~L}$ high, and retain CCR7 expression [14] and lymphoid homing potential. "Effector memory T cells" $\left(\mathrm{T}_{\mathrm{EM}}\right)$ are CD44 ${ }^{\text {high }}, \mathrm{CD} \mathrm{L}^{\text {low }}$, and $\mathrm{CCR}^{-}$, and preferentially circulate though the bloodstream and into through peripheral non-lymphoid tissues [14]. $\mathrm{T}_{\mathrm{EM}}$ form one of the four memory CD8 $\mathrm{T}$ cell subsets found in lung and airways, and do not express CD49a, CD103, and CD69. CD49a/VLA-1 is the only known integrin ligand for collagen $\mathrm{IV}$, uniquely located in the lamina densa of barrier tissues, though it has been shown to also bind collagen I [20]. It provides anti-apoptotic signals to the T cells when bound to collagen [21] and has proven essential for maintaining $\mathrm{T}_{\mathrm{RM}}$ in peripheral tissues. $\mathrm{T}$ cells that express CD49a/VLA-1 tend 
to localize close to or within the epithelial cell layer where collagen IV is abundant [22]. CD69 is an S1P1 antagonist, limiting signals that direct lymphocytes into draining lymphatics [23,24]. It is also a ligand for Galectin-1 (Gal-1) and may have a role in cell-cell and cell-matrix interactions [25]. CD103 is a ligand for E-cadherin, which is most widely expressed in the junctions between epithelial cells at mucosal and barrier sites [26]. Both CD8 T cells and dendritic cells (DC) can also express this ligand for CD103, two more sources of potential cell-cell interaction [27]. CD103 is also expressed on a subset of DC in the airways that serve to sample the epithelium for antigen by interaction with cell junctions [28], possibly playing a similar role for CD8 $\mathrm{T}_{\mathrm{RM}}$ cells in epithelial surveillance. Expression of these adhesion and migratory receptors may position memory $\mathrm{T}$ cell subsets in different locations in the mucosa depending on ligand availability (Figure 1, Table 2)

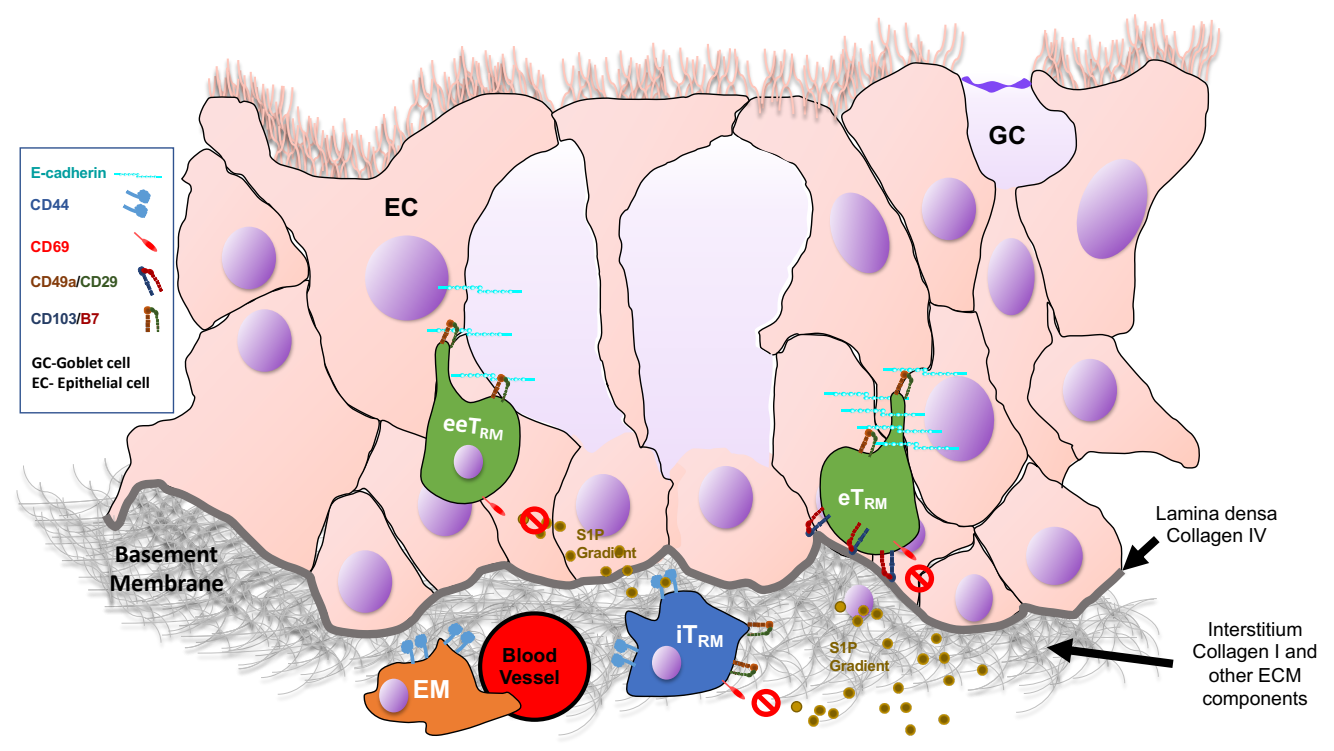

Figure 1. Proposed tissue localization of CD8+ memory T cell subsets within epithelial tissue. Based on the expression of adhesion molecules for ECM (CD49a, CD44) and, epithelial cells (CD103), and the location of their ligands, the memory cell subsets may be positioned in different tissue microenvironments.

Table 2. Select markers of memory CD8 T cell subsets and their functions.

\begin{tabular}{llc}
\hline \multicolumn{1}{c}{ Marker } & \multicolumn{1}{c}{ Function } & Presence on $\mathbf{T}_{\mathbf{R M}}$ \\
\hline CD44 & $\begin{array}{l}\text { Binds hyaluronic acids. May serve roles in } \\
\text { motility and retention in both peripheral } \\
\text { and lymphoid tissues. }\end{array}$ & +/High \\
\hline CD62L & Ligand for high endothelial venules on SLO. & -/Low \\
\hline CCR7 & Chemokine receptor for S1P1. & -/Low \\
\hline CD49a & Mediates adhesion to type I and IV collagen. & Positive on most $\mathrm{T}_{\mathrm{RM}}$ \\
\hline CD69 & $\begin{array}{l}\text { Early activation marker. S1P1R antagonist. } \\
\text { Binds Gal-1. }\end{array}$ & $\begin{array}{c}\text { Positive on most } \mathrm{T}_{\mathrm{RM}} \\
\text { CD103 }\end{array}$ \\
\hline
\end{tabular}

Note: "+" indicates positive cell surface expression; "-" indicated negative cell surface expression.

\section{Formation of CD8 $T_{R M}$ and Interactions with Other Cells in the Tissue}

Virus-specific CD8 cells that express CD49a do not appear in the tissue until after the infection is cleared [4]. In influenza infection, CD8 T cells in the tissue express CD49a, CD69, and CD103 by day 14 , suggesting cells with a $T_{R M}$ phenotype develop relatively early as the tissue recovers from 
infection [12]. There has been much speculation regarding when and where $\mathrm{T}_{\mathrm{RM}}$ cells form: Takamura demonstrated that in areas of repair after influenza infection, there are repair-associated memory depots (RAMD) containing populations of keratin-5+ cells that express alpha-V integrins [29]. Alpha-V integrins can activate latent TGF- $\beta$ in the tissue, a necessary cytokine for $T_{R M}$ to express CD49a and CD103 $[30,31]$. This suggests the $T_{\mathrm{RM}}$ cells form directly in the tissues they take residence in.

However, this hypothesis does not explain the early observations that pathogen-specific $\mathrm{T}_{\mathrm{RM}}$ can be found in all peripheral tissues examined regardless of whether they were directly infected [4]. Experiments using FTY720 to block S1P signaling and inhibit lymph node (LN) egress resulted in an accumulation of CD8 $\mathrm{T}$ cells bearing the $\mathrm{T}_{\mathrm{RM}}$ phenotype in the lymph nodes (Topham unpublished). In such an experiment it is difficult to discern in situ differentiation of $\mathrm{T}_{\mathrm{RM}}$ in the $\mathrm{LN}$ from drainage of the cells out of the tissues, but it does question whether $\mathrm{T}_{\mathrm{RM}}$ cells solely develop in the recovering tissue, and also suggests there may be a window after infection during which $\mathrm{T}_{\mathrm{RM}}$ cells disperse systemically to peripheral tissues. Takamura's parabiosis experiments suggest that mice need to be paired by day 6 after infection to show distribution of virus specific cells to lungs and other tissues of both mice [29]. However, more focused tracking experiments will need to be done to concretely answer this question.

Additional signals in the tissue may be needed to generate $\mathrm{T}_{\mathrm{RM}}$. Using a push-pull strategy, the Kohlmeier lab recently demonstrated that encounter with antigen in the tissue may be required for $\mathrm{T}_{\mathrm{RM}}$ localization [32]. Using an intramuscular infection model and intranasal administration of CpG or CpG plus nucleoprotein (NP) peptide, only the animals given local peptide developed substantial $\mathrm{NP}$-specific $\mathrm{T}_{\mathrm{RM}}$ cells in the respiratory tract [32]. Antigen encounter has been shown to down-regulate CCR7 on recently activated T cells perhaps explaining the need for antigen to be present for optimal $\mathrm{T}_{\mathrm{RM}}$ formation [33-35].

A role for IL-10 has also been indicated in the production of monocyte-derived TGF- $\beta$; a critical mediator for upregulation of CD103 (and possibly CD49a) in several studies [36-38]. These experiments used various adjuvants and antigen in vivo, and an in vitro model of $\mathrm{T}$ cell activation to induce an immune response. With this system, T cells exposed to IL10 and TGF- $\beta$ very early in priming had the highest levels of CD103, suggesting $\mathrm{T}_{\mathrm{RM}}$ precursors could be generated in the $\mathrm{LN}$ [38]. This scenario of early exposure to these cytokines is less likely to occur in models of infection given the slow kinetics (days) and levels of IL-10, which are not high early in a flu infection [39], but antigen-bearing monocytes releasing Transforming Growth Factor (TGF) $-\beta$ directly in relation to $\mathrm{T}_{\mathrm{RM}}$ development has not been studied in the context of infection.

It is also possible that CD103 could be expressed prior to other $T_{R M}$ markers, and inhibition of $\mathrm{CD} 103$ leads to reduced numbers of $\mathrm{T}_{\mathrm{RM}}$, consistent with a role in the accumulation in tissues [23]. Although these papers did not look at the function of CD49a, in a gut model of $T_{R M}$, TGF- $\beta$ was shown to be important for expression of CD49 on a $4 b 7+$ gut $T_{R M}$ [37] In an influenza infection model, another stimulatory signal for $\mathrm{T}_{\mathrm{RM}}$ formation comes from 4-1BB [40]. 4-1BB is a TNF family receptor and endogenous signals from antigen-bearing 4-1BB ligand expressing cells in the tissue enhance $\mathrm{T}_{\mathrm{RM}}$ formation while exogenous administration of $4-1 \mathrm{BB}$ ligand further expands the number of $\mathrm{T}_{\mathrm{RM}}$ formed [40].

\section{Metabolic Changes Associated with $T_{R M}$}

Tissues like skin, gut, and respiratory mucosa are very different environments than Secondary Lymphoid Organ (SLO)s and blood. The availability of nutrients such as glucose and oxygen vary compared to SLOs. The metabolic pathways utilized by $\mathrm{T}$ cells has been shown to vary with their state of activation [41]. As with most eukaryotic cells, naïve T cells primarily derive energy from oxidative phosphorylation in the mitochondria [42] to make adenosine triphosphate (ATP). T cell activation drives T cell metabolism toward aerobic glycolysis, the pentose phosphate pathway, and glutaminolysis [43]. These changes are associated with reprogramming of the metabolic transcriptome [44,45]. The different circulating memory $\mathrm{T}$ cells subsets utilize distinct metabolic programs. For example, central memory 
$\mathrm{T}$ cells primarily use oxidative phosphorylation, much like naïve T cells [42,46]. Effector memory $\mathrm{T}$ cells that can circulate through peripheral tissues use a more balanced combination of oxidative phosphorylation and glycolysis and have greater mitochondrial mass that makes them more comparable to effector T cells [47].

Peripheral tissues, especially barrier tissues and microcompartments contained within these offer different glucose levels, $\mathrm{pH}$, and structural components, all of which can affect $\mathrm{T}$ cell metabolism and survival. $\mathrm{T}_{\mathrm{RM}}$ cells are very active in the "resting" state as they constantly perform surveillance of the cells surrounding them for evidence of pathogen invasion. $\mathrm{T}_{\mathrm{RM}}$ cells intimately interact with the components of their environment including epithelial cells and the extracellular matrix. $\mathrm{T}_{\mathrm{RM}}$ cells abundantly express lipid receptors on their cell surface to provide them capacity for lipid uptake and metabolism [48]. These include fatty acid binding proteins FABP4, FABP5 to enhance lipolysis, low density lipid receptor, $\mathrm{ApoE}$, and the CD36 scavenger receptor. These receptors facilitate uptake of free fatty acids (FFA) from the environment and these FFA can be used in oxidative phosphorylation and in fatty acid oxidation (FAO) [49]. $\mathrm{T}_{\mathrm{RM}}$ can accumulate FFA in droplets within the cytoplasm just like $\mathrm{T}_{\mathrm{EM}}$ are able to do [50], and these droplets can be coupled to distinct mitochondria upon activation [51,52]. $\mathrm{T}_{\mathrm{RM}}$ may rely on traditional oxidative phosphorylation and glycolysis under "resting" conditions, and activate FAO by accessing the stored droplets upon encounter with pathogens and antigen recognition, however, this has yet to be directly tested.

\section{Mechanisms that Suppress $T_{R M}$ Activation May Have other Functions Important to $T_{R M}$ Establishment and Maintenance}

$\mathrm{CD} 8 \mathrm{~T}_{\mathrm{RM}}$ cells are armed and ready to protect against secondary infections. They can express high levels of Granzyme B giving them cytotoxic potential, secrete IFN- $\gamma$ and TNF- $\alpha$ when activated, as well as a laundry list of chemokines to jumpstart immune cell recruitment [41]. Therefore, accidental or bystander activation of $\mathrm{T}_{\mathrm{RM}}$ could result in serious, unwanted tissue damage. There are a number of inhibitory receptors expressed by CD8 $\mathrm{T}_{\mathrm{RM}}$ that likely serve to keep these cells at bay until bona fide antigen recognition occurs through the TCR. Brain $\mathrm{T}_{\mathrm{RM}}$ cells express PD1, a receptor associated with $\mathrm{T}$ cell exhaustion and inability to activate [53,54]. Blockade of PD-1 ligand in tumor settings greatly enhances $\mathrm{T}$ cell elimination of cancer cells [55]. How this suppression is overcome in $\mathrm{T}_{\mathrm{RM}}$ during an infection is not known and may require a combination of "activating" signals. P2RX7 is a purinergic receptor expressed by $\mathrm{T}_{\mathrm{RM}}$ [56]. Low ATP levels and signals through P2RX7 can promote $\mathrm{T}_{\mathrm{RM}}$ survival by stimulating activation and metabolism. High signals, on the other hand, can drive $\mathrm{T}$ cell apoptosis [56], making the balance of signals in the environment of $\mathrm{T}_{\mathrm{RM}}$ critical. $\mathrm{T}_{\mathrm{RM}}$ cells also express CD244, a receptor previously described on Natural Killer (NK) cells [57]. Signals through CD244 can be either inhibitory or activating depending on intracellular levels of the adapter protein Signaling Lymphocytic Activation Molecule (SLAM) associated protein (SAP) [58]. SAP levels in $\mathrm{T}_{\mathrm{RM}}$ are not known, but this knowledge could further indicate how these, and other receptors regulate $\mathrm{T}_{\mathrm{RM}}$ maintenance and function. Collectively, these inhibitory molecules may keep $\mathrm{T}_{\mathrm{RM}}$ in a state of readiness to respond, but inhibiting aberrant activation of $\mathrm{T}_{\mathrm{RM}}$ by non-specific environmental cues.

\section{Concluding Remarks}

$\mathrm{T}_{\mathrm{RM}}$ cells represent a very specialized subset of memory $\mathrm{T}$ cells that can be highly protective during secondary encounters with a previously seen pathogen. While not discussed here, they also seem to be important in controlling tumor cells and CD103 expression has been suggested as a predictor of tumor prognosis [59]. They have specialized functions that permit them to perform surveillance and protection at a number of barrier sites, including but not limited to skin, gut, respiratory tract, and female reproductive tract. However, many questions remain in our understanding of this unique cell subset. For example, we don't fully appreciate why they seem to wane with time in some tissues, while they are continuously renewed in others. We also do not have effective, clinically feasible strategies of generating, maintaining, or improving their numbers. Live attenuated vaccines 
do generate a population of $\mathrm{T}_{\mathrm{RM}}$ cells, however at a weakened capacity compared with natural infection $[60,61]$. Additionally, to date, $\mathrm{T}_{\mathrm{RM}}$ cells are considered as one uniform population of cells and we believe that research examining $\mathrm{T}_{\mathrm{RM}}$ subsets is lacking. For example, do all $\mathrm{T}_{\mathrm{RM}}$ cells express $\mathrm{CD} 69$, CD49a, or CD103? Do populations exist that express different combinations of these markers? What are the genetic and epigenetic programs that drive their phenotype(s)? What are the mechanisms of controlling motility, persistence, and micro-localization within different tissues? In what ways, if at all, are $\mathrm{T}_{\mathrm{RM}}$ cells specific for viruses different than those specific for bacteria, fungi, cancer, or other pathologies? These are all important questions the field needs to address to construct a more holistic model through which we cannot only understand memory and immunity, but use them to develop more effective vaccines and therapies.

Author Contributions: D.J.T. organized the review and wrote the text; E.C.R. edited the manuscript and contributed data; K.L.E. edited the manuscript; M.S. edited the manuscript and drew Figure 1.

Funding: This research was funded by National Institutes of Health/National Institute of Allergy and Infectious Disease grant number 2P01-AI102851 and National Institute of General Medical Sciences Medical Scientist Training Program T32 GM007356.

Conflicts of Interest: The authors declare no conflict of interest.

\section{References}

1. Liang, S.; Mozdzanowska, K.; Palladino, G.; Gerhard, W. Heterosubtypic immunity to influenza type A virus in mice. Effector mechanisms and their longevity. J. Immunol. 1994, 152, 1653-1661. [PubMed]

2. Hogan, R.J.; Usherwood, E.J.; Zhong, W.; Roberts, A.A.; Dutton, R.W.; Harmsen, A.G.; Woodland, D.L. Activated antigen-specific CD8+ $\mathrm{T}$ cells persist in the lungs following recovery from respiratory virus infections. J. Immunol. 2001, 166, 1813-1822. [CrossRef] [PubMed]

3. Masopust, D.; Vezys, V.; Marzo, A.L.; Lefrancois, L. Preferential localization of effector memory cells in nonlymphoid tissue. Science 2001, 291, 2413-2417. [CrossRef] [PubMed]

4. Ray, S.J.; Franki, S.N.; Pierce, R.H.; Dimitrova, S.; Koteliansky, V.; Sprague, A.G.; Doherty, P.C.; de Fougerolles, A.R.; Topham, D.J. The collagen binding alpha1beta1 integrin VLA-1 regulates CD8 T cell-mediated immune protection against heterologous influenza infection. Immunity 2004, 20, 167-179. [CrossRef]

5. Teijaro, J.R.; Turner, D.; Pham, Q.; Wherry, E.J.; Lefrancois, L.; Farber, D.L. Cutting edge: Tissue-retentive lung memory CD4 T cells mediate optimal protection to respiratory virus infection. J. Immunol. 2011, 187, 5510-5514. [CrossRef]

6. Sallusto, F.; Lenig, D.; Forster, R.; Lipp, M.; Lanzavecchia, A. Two subsets of memory T lymphocytes with distinct homing potentials and effector functions [see comments]. Nature 1999, 401, 708-712. [CrossRef]

7. Woodberry, T.; Suscovich, T.J.; Henry, L.M.; August, M.; Waring, M.T.; Kaur, A.; Hess, C.; Kutok, J.L.; Aster, J.C.; Wang, F.; et al. Alpha E beta 7 (CD103) expression identifies a highly active, tonsil-resident effector-memory CTL population. J. Immunol. 2005, 175, 4355-4362. [CrossRef]

8. Wakim, L.M.; Woodward-Davis, A.; Bevan, M.J. Memory T cells persisting within the brain after local infection show functional adaptations to their tissue of residence. Proc. Natl. Acad. Sci. USA 2010, 107, 17872-17879. [CrossRef]

9. Kumar, B.V.; Ma, W.; Miron, M.; Granot, T.; Guyer, R.S.; Carpenter, D.J.; Senda, T.; Sun, X.; Ho, S.H.; Lerner, H.; et al. Human Tissue-Resident Memory T Cells Are Defined by Core Transcriptional and Functional Signatures in Lymphoid and Mucosal Sites. Cell Rep. 2017, 20, 2921-2934. [CrossRef]

10. Mackay, L.K.; Minnich, M.; Kragten, N.A.; Liao, Y.; Nota, B.; Seillet, C.; Zaid, A.; Man, K.; Preston, S.; Freestone, D.; et al. Hobit and Blimp1 instruct a universal transcriptional program of tissue residency in lymphocytes. Science 2016, 352, 459-463. [CrossRef]

11. Walsh, D.A.; Borges da Silva, H.; Beura, L.K.; Peng, C.; Hamilton, S.E.; Masopust, D.; Jameson, S.C. The Functional Requirement for CD69 in Establishment of Resident Memory CD8(+) T Cells Varies with Tissue Location. J. Immunol. 2019, 203, 946-955. [CrossRef] [PubMed] 
12. Reilly, E.C.; Lambert-Emo, K.; Reilly, N.; Chaves, F.A.; Oakes, P.; Topham, D.J. TRM Integrins CD103 and CD49a Differentially Support Adherence and Motility After Resolution of Influenza Virus Infection. Proc. Natl. Acad. Sci. USA 2019, in press.

13. Topham, D.J.; Reilly, E.C. Tissue-Resident Memory CD8(+) T Cells: From Phenotype to Function. Front. Immunol. 2018, 9, 515. [CrossRef] [PubMed]

14. Sallusto, F.; Geginat, J.; Lanzavecchia, A. Central memory and effector memory T cell subsets: function, generation, and maintenance. Annu. Rev. Immunol. 2004, 22, 745-763. [CrossRef] [PubMed]

15. Spertini, O.; Luscinskas, F.W.; Kansas, G.S.; Munro, J.M.; Griffin, J.D.; Gimbrone, M.A., Jr.; Tedder, T.F. Leukocyte adhesion molecule-1 (LAM-1, L-selectin) interacts with an inducible endothelial cell ligand to support leukocyte adhesion. J. Immunol. 1991, 147, 2565-2573.

16. Sallusto, F.; Kremmer, E.; Palermo, B.; Hoy, A.; Ponath, P.; Qin, S.; Forster, R.; Lipp, M.; Lanzavecchia, A. Switch in chemokine receptor expression upon TCR stimulation reveals novel homing potential for recently activated T cells. Eur. J. Immunol. 1999, 29, 2037-2045. [CrossRef]

17. Debes, G.F.; Hopken, U.E.; Hamann, A. In vivo differentiated cytokine-producing CD4(+) T cells express functional CCR7. J. Immunol. 2002, 168, 5441-5447. [CrossRef]

18. Lazaar, A.L.; Albelda, S.M.; Pilewski, J.M.; Brennan, B.; Pure, E.; Panettieri, R.A., Jr. T lymphocytes adhere to airway smooth muscle cells via integrins and CD44 and induce smooth muscle cell DNA synthesis. J. Exp. Med. 1994, 180, 807-816. [CrossRef]

19. Mrass, P.; Kinjyo, I.; Ng, L.G.; Reiner, S.L.; Pure, E.; Weninger, W. CD44 mediates successful interstitial navigation by killer T cells and enables efficient antitumor immunity. Immunity 2008, 29, 971-985. [CrossRef]

20. Bank, I.; Book, M.; Ware, R. Functional role of VLA-1 (CD49A) in adhesion, cation-dependent spreading, and activation of cultured human T lymphocytes. Cell Immunol. 1994, 156, 424-437. [CrossRef]

21. Richter, M.V.; Topham, D.J. The alpha1beta1 integrin and TNF receptor II protect airway CD8+ effector T cells from apoptosis during influenza infection. J. Immunol. 2007, 179, 5054-5063. [CrossRef] [PubMed]

22. Richter, M.; Ray, S.J.; Chapman, T.J.; Austin, S.J.; Rebhahn, J.; Mosmann, T.R.; Gardner, H.; Kotelianski, V.; de Fougerolles, A.R.; Topham, D.J. Collagen distribution and expression of collagen-binding alpha1beta1 (VLA-1) and alpha2beta1 (VLA-2) integrins on CD4 and CD8 T cells during influenza infection. J. Immunol. 2007, 178, 4506-4516. [CrossRef]

23. Lee, Y.T.; Suarez-Ramirez, J.E.; Redman, J.M.; Aguila, C.C.; Hadley, G.A.; Cauley, L.S. CD69 and CD103 cooperatively regulate CD8 T cell responses in the lungs after viral infection. J. Immunol. 2009, 182.

24. Lee, Y.T.; Suarez-Ramirez, J.E.; Wu, T.; Redman, J.M.; Bouchard, K.; Hadley, G.A.; Cauley, L.S. Environmental and antigen receptor-derived signals support sustained surveillance of the lungs by pathogen-specific cytotoxic T lymphocytes. J. Virol. 2011, 85, 4085-4094. [CrossRef] [PubMed]

25. Cibrian, D.; Sanchez-Madrid, F. CD69: from activation marker to metabolic gatekeeper. Eur. J. Immunol. 2017, 47, 946-953. [CrossRef] [PubMed]

26. Pauls, K.; Schon, M.; Kubitza, R.C.; Homey, B.; Wiesenborn, A.; Lehmann, P.; Ruzicka, T.; Parker, C.M.; Schon, M.P. Role of integrin alphaE(CD103)beta7 for tissue-specific epidermal localization of CD8+ T lymphocytes. J. Invest. Dermatol. 2001, 117, 569-575. [CrossRef] [PubMed]

27. Cepek, K.L.; Rimm, D.L.; Brenner, M.B. Expression of a candidate cadherin in T lymphocytes. Proc. Natl. Acad. Sci. USA 1996, 93, 6567-6571. [CrossRef]

28. Sung, S.S.J.; Fu, S.M.; Rose, C.E.; Gaskin, F.; Ju, S.T.; Beaty, S.R. A Major Lung CD103 ( E)- 7 Integrin-Positive Epithelial Dendritic Cell Population Expressing Langerin and Tight Junction Proteins. J. Immunol. 2006, 176, 2161-2172. [CrossRef]

29. Takamura, S.; Yagi, H.; Hakata, Y.; Motozono, C.; McMaster, S.R.; Masumoto, T.; Fujisawa, M.; Chikaishi, T.; Komeda, J.; Itoh, J.; et al. Specific niches for lung-resident memory CD8+ T cells at the site of tissue regeneration enable CD69-independent maintenance. J. Exp. Med. 2016, 213, 3057-3073. [CrossRef]

30. Casey, K.A.; Fraser, K.A.; Schenkel, J.M.; Moran, A.; Abt, M.C.; Beura, L.K.; Lucas, P.J.; Artis, D.; Wherry, E.J.; Hogquist, K.; et al. Antigen-independent differentiation and maintenance of effector-like resident memory $\mathrm{T}$ cells in tissues. J. Immunol. 2012, 188, 4866-4875. [CrossRef]

31. Mackay, L.K.; Wynne-Jones, E.; Freestone, D.; Pellicci, D.G.; Mielke, L.A.; Newman, D.M.; Braun, A.; Masson, F.; Kallies, A.; Belz, G.T.; et al. T-box Transcription Factors Combine with the Cytokines TGF-beta and IL-15 to Control Tissue-Resident Memory T Cell Fate. Immunity 2015, 43, 1101-1111. [CrossRef] [PubMed] 
32. McMaster, S.R.; Wein, A.N.; Dunbar, P.R.; Hayward, S.L.; Cartwright, E.K.; Denning, T.L.; Kohlmeier, J.E. Pulmonary antigen encounter regulates the establishment of tissue-resident CD8 memory $\mathrm{T}$ cells in the lung airways and parenchyma. Mucosal Immunol. 2018, 11, 1071-1078. [CrossRef] [PubMed]

33. Bromley, S.K.; Thomas, S.Y.; Luster, A.D. Chemokine receptor CCR7 guides T cell exit from peripheral tissues and entry into afferent lymphatics. Nat. Immunol. 2005, 6, 895-901. [CrossRef] [PubMed]

34. Debes, G.F.; Arnold, C.N.; Young, A.J.; Krautwald, S.; Lipp, M.; Hay, J.B.; Butcher, E.C. Chemokine receptor CCR7 required for T lymphocyte exit from peripheral tissues. Nat. Immunol. 2005, 6, 889-894. [CrossRef]

35. Jennrich, S.; Lee, M.H.; Lynn, R.C.; Dewberry, K.; Debes, G.F. Tissue exit: a novel control point in the accumulation of antigen-specific CD8 T cells in the influenza a virus-infected lung. J. Virol. 2012, 86, 3436-3445. [CrossRef]

36. Thompson, E.A.; Darrah, P.A.; Foulds, K.E.; Hoffer, E.; Caffrey-Carr, A.; Norenstedt, S.; Perbeck, L.; Seder, R.A.; Kedl, R.M.; Lore, K. Monocytes Acquire the Ability to Prime Tissue-Resident T Cells via IL-10-Mediated TGF-beta Release. Cell. Rep. 2019, 28, 1127-1135 e1124. [CrossRef]

37. Zhang, N.; Bevan, M.J. Transforming growth factor-beta signaling controls the formation and maintenance of gut-resident memory $\mathrm{T}$ cells by regulating migration and retention. Immunity 2013, 39, 687-696. [CrossRef]

38. Nath, A.P.; Braun, A.; Ritchie, S.C.; Carbone, F.R.; Mackay, L.K.; Gebhardt, T.; Inouye, M. Comparative analysis reveals a role for TGF-beta in shaping the residency-related transcriptional signature in tissue-resident memory CD8+ T cells. PLoS ONE 2019, 14, e0210495. [CrossRef]

39. McKinstry, K.K.; Strutt, T.M.; Buck, A.; Curtis, J.D.; Dibble, J.P.; Huston, G.; Tighe, M.; Hamada, H.; Sell, S.; Dutton, R.W.; et al. IL-10 deficiency unleashes an influenza-specific Th17 response and enhances survival against high-dose challenge. J. Immunol. 2009, 182, 7353-7363. [CrossRef]

40. Zhou, A.C.; Batista, N.V.; Watts, T.H. 4-1BB Regulates Effector CD8 T Cell Accumulation in the Lung Tissue through a TRAF1-, mTOR-, and Antigen-Dependent Mechanism to Enhance Tissue-Resident Memory T Cell Formation during Respiratory Influenza Infection. J. Immunol. 2019, 202, 2482-2492. [CrossRef]

41. Konjar, S.; Veldhoen, M. Dynamic Metabolic State of Tissue Resident CD8 T Cells. Front. Immunol. 2019, 10, 1683. [CrossRef] [PubMed]

42. Fox, C.J.; Hammerman, P.S.; Thompson, C.B. Fuel feeds function: energy metabolism and the T-cell response. Nat. Rev. Immunol. 2005, 5, 844-852. [CrossRef] [PubMed]

43. Doedens, A.L.; Phan, A.T.; Stradner, M.H.; Fujimoto, J.K.; Nguyen, J.V.; Yang, E.; Johnson, R.S.; Goldrath, A.W. Hypoxia-inducible factors enhance the effector responses of CD8(+) T cells to persistent antigen. Nat. Immunol. 2013, 14, 1173-1182. [CrossRef] [PubMed]

44. Macintyre, A.N.; Finlay, D.; Preston, G.; Sinclair, L.V.; Waugh, C.M.; Tamas, P.; Feijoo, C.; Okkenhaug, K.; Cantrell, D.A. Protein kinase B controls transcriptional programs that direct cytotoxic $\mathrm{T}$ cell fate but is dispensable for T cell metabolism. Immunity 2011, 34, 224-236. [CrossRef]

45. Wang, R.; Dillon, C.P.; Shi, L.Z.; Milasta, S.; Carter, R.; Finkelstein, D.; McCormick, L.L.; Fitzgerald, P.; Chi, H.; Munger, J.; et al. The transcription factor Myc controls metabolic reprogramming upon T lymphocyte activation. Immunity 2011, 35, 871-882. [CrossRef]

46. Maekawa, Y.; Ishifune, C.; Tsukumo, S.; Hozumi, K.; Yagita, H.; Yasutomo, K. Notch controls the survival of memory CD4+ T cells by regulating glucose uptake. Nat. Med. 2015, 21, 55-61. [CrossRef]

47. Van der Windt, G.J.; Everts, B.; Chang, C.H.; Curtis, J.D.; Freitas, T.C.; Amiel, E.; Pearce, E.J.; Pearce, E.L. Mitochondrial respiratory capacity is a critical regulator of CD8+ T cell memory development. Immunity 2012, 36, 68-78. [CrossRef]

48. Fahrer, A.M.; Konigshofer, Y.; Kerr, E.M.; Ghandour, G.; Mack, D.H.; Davis, M.M.; Chien, Y.H. Attributes of gammadelta intraepithelial lymphocytes as suggested by their transcriptional profile. Proc. Natl. Acad. Sci. USA 2001, 98, 10261-10266. [CrossRef]

49. Pan, Y.; Tian, T.; Park, C.O.; Lofftus, S.Y.; Mei, S.; Liu, X.; Luo, C.; O’Malley, J.T.; Gehad, A.; Teague, J.E.; et al. Survival of tissue-resident memory T cells requires exogenous lipid uptake and metabolism. Nature 2017, 543, 252-256. [CrossRef]

50. Konjar, S.; Frising, U.C.; Ferreira, C.; Hinterleitner, R.; Mayassi, T.; Zhang, Q.; Blankenhaus, B.; Haberman, N.; Loo, Y.; Guedes, J.; et al. Mitochondria maintain controlled activation state of epithelial-resident T lymphocytes. Sci. Immunol. 2018, 3. [CrossRef]

51. Benador, I.Y.; Veliova, M.; Liesa, M.; Shirihai, O.S. Mitochondria Bound to Lipid Droplets: Where Mitochondrial Dynamics Regulate Lipid Storage and Utilization. Cell Metab 2019, 29, 827-835. [CrossRef] [PubMed] 
52. Benador, I.Y.; Veliova, M.; Mahdaviani, K.; Petcherski, A.; Wikstrom, J.D.; Assali, E.A.; Acin-Perez, R.; Shum, M.; Oliveira, M.F.; Cinti, S.; et al. Mitochondria Bound to Lipid Droplets Have Unique Bioenergetics, Composition, and Dynamics that Support Lipid Droplet Expansion. Cell Metab. 2018, 27, 869-885 e866. [CrossRef] [PubMed]

53. Prasad, S.; Hu, S.; Sheng, W.S.; Chauhan, P.; Singh, A.; Lokensgard, J.R. The PD-1: PD-L1 pathway promotes development of brain-resident memory $\mathrm{T}$ cells following acute viral encephalitis. J. Neuroinflammation 2017, 14, 82. [CrossRef] [PubMed]

54. Shwetank; Frost, E.L.; Mockus, T.E.; Ren, H.M.; Toprak, M.; Lauver, M.D.; Netherby-Winslow, C.S.; Jin, G.; Cosby, J.M.; Evavold, B.D.; et al. PD-1 Dynamically Regulates Inflammation and Development of Brain-Resident Memory CD8 T Cells During Persistent Viral Encephalitis. Front. Immunol. 2019, 10, 783. [CrossRef]

55. Peggs, K.S.; Quezada, S.A. PD-1 blockade: promoting endogenous anti-tumor immunity. Expert Rev. Anticancer Ther. 2012, 12, 1279-1282. [CrossRef]

56. Borges da Silva, H.; Beura, L.K.; Wang, H.; Hanse, E.A.; Gore, R.; Scott, M.C.; Walsh, D.A.; Block, K.E.; Fonseca, R.; Yan, Y.; et al. The purinergic receptor P2RX7 directs metabolic fitness of long-lived memory CD8(+) T cells. Nature 2018, 559, 264-268. [CrossRef] [PubMed]

57. Konjar, S.; Ferreira, C.; Blankenhaus, B.; Veldhoen, M. Intestinal Barrier Interactions with Specialized CD8 T Cells. Front. Immunol. 2017, 8, 1281. [CrossRef] [PubMed]

58. Waggoner, S.N.; Kumar, V. Evolving role of 2B4/CD244 in T and NK cell responses during virus infection. Front. Immunol. 2012, 3, 377. [CrossRef] [PubMed]

59. Edwards, J.; Wilmott, J.S.; Madore, J.; Gide, T.N.; Quek, C.; Tasker, A.; Ferguson, A.; Chen, J.; Hewavisenti, R.; Hersey, P.; et al. CD103(+) Tumor-Resident CD8(+) T Cells Are Associated with Improved Survival in Immunotherapy-Naive Melanoma Patients and Expand Significantly During Anti-PD-1 Treatment. Clin. Cancer Res. Offic. J. Am. Assoc. Cancer Res. 2018, 24, 3036-3045. [CrossRef]

60. Horvath, K.M.; Brighton, L.E.; Herbst, M.; Noah, T.L.; Jaspers, I. Live attenuated influenza virus (LAIV) induces different mucosal $\mathrm{T}$ cell function in nonsmokers and smokers. Clin. Immunol. 2012, 142, 232-236. [CrossRef]

61. Xu, X.; Wang, H.; Liu, Y.; Wang, Y.; Zeng, L.; Wu, K.; Wang, J.; Ma, F.; Xu, W.; Yin, Y.; et al. Mucosal immunization with the live attenuated vaccine SPY1 induces humoral and Th2-Th17-regulatory $\mathrm{T}$ cell cellular immunity and protects against pneumococcal infection. Infect. Immun. 2015, 83, 90-100. [CrossRef] [PubMed]

(C) 2019 by the authors. Licensee MDPI, Basel, Switzerland. This article is an open access article distributed under the terms and conditions of the Creative Commons Attribution (CC BY) license (http://creativecommons.org/licenses/by/4.0/). 